\title{
Neurotransmitter- and Growth Factor-Induced cAMP Response Element Binding Protein Phosphorylation in Glial Cell Progenitors: Role of Calcium Ions, Protein Kinase C, and Mitogen-Activated Protein Kinase/Ribosomal S6 Kinase Pathway
}

\author{
Mario Pende, ${ }^{1}$ Tracey L. Fisher, ${ }^{2}$ Peter B. Simpson, ${ }^{1}$ James T. Russell, ${ }^{1}$ John Blenis, ${ }^{2}$ and Vittorio Gallo ${ }^{1}$ \\ ${ }^{1}$ Laboratory of Cellular and Molecular Neurophysiology, National Institute of Child Health and Human Development, \\ National Institutes of Health, Bethesda, Maryland 20892, and 2Department of Cell Biology, Harvard Medical School, \\ Boston, Massachusetts 02115
}

\begin{abstract}
To understand how extracellular signals may produce longterm effects in neural cells, we have analyzed the mechanism by which neurotransmitters and growth factors induce phosphorylation of the transcription factor CAMP response element binding protein (CREB) in cortical oligodendrocyte progenitor (OP) cells. Activation of glutamate receptor channels by kainate, as well as stimulation of G-protein-coupled cholinergic receptors by carbachol and tyrosine kinase receptors by basic fibroblast growth factor (bFGF), rapidly leads to mitogenactivated protein kinase (MAPK) phosphorylation and ribosomal S6 kinase (RSK) activation. Kainate and carbachol activation of the MAPK pathway requires extracellular calcium influx and is accompanied by protein kinase $\mathrm{C}$ (PKC) induction, with no significant increase in GTP binding to Ras. Conversely, growth factor-stimulated MAPK phosphorylation is independent of extracellular calcium and is accompanied by Ras acti-
\end{abstract}

vation. Both basal and stimulated MAPK activity in OP cells are influenced by cytoplasmic calcium levels, as shown by their sensitivity to the calcium chelator bis(2-aminophenoxy)ethane$N, N, N^{\prime}, N^{\prime}$-tetra-acetic acid. The kinetics of CREB phosphorylation in response to the various agonists corresponds to that of MAPK activation. Moreover, CREB phosphorylation and MAPK activation are similarly affected by calcium ions. The MEK inhibitor PD 098059, which selectively prevents activation of the MAPK pathway, strongly reduces induction of CREB phosphorylation by kainate, carbachol, bFGF, and the phorbol ester TPA. We propose that in OPs the MAPK/RSK pathway mediates CREB phosphorylation in response to calcium influx, PKC activation, and growth factor stimulation.

Key words: non-NMDA receptors; muscarinic receptors; basic fibroblast growth factor; ribosomal S6 kinase; transcription factor; oligodendrocytes
Calcium ions act as second messengers in the CNS (Clapham, 1995). Extracellular signals can increase intracellular calcium concentration $\left(\left[\mathrm{Ca}^{2+}\right]_{\mathrm{i}}\right)$ and initiate signal transduction through different mechanisms. The activation of G-protein-coupled receptors or growth factor receptors can stimulate phospholipase $\mathrm{C}$ to produce inositol $(1,4,5)$-trisphosphate $\left(\mathrm{InsP}_{3}\right)$ and diacylglycerol. $\mathrm{InsP}_{3}$ triggers $\mathrm{Ca}^{2+}$ release from the endoplasmic reticulum (Berridge and Irvine, 1989), which is typically followed by capacitative entry of $\mathrm{Ca}^{2+}$ across the plasma membrane through storeoperated channels (Clapham, 1996). Excitatory neurotransmitters can lead directly to $\mathrm{Ca}^{2+}$ influx through the opening of receptor channels permeable to this cation (Mayer and Miller, 1990). Finally, activation of receptor channels that depolarize the cell membrane can indirectly increase $\left[\mathrm{Ca}^{2+}\right]_{i}$ through the gating of voltage-sensitive $\mathrm{Ca}^{2+}$ channels.

$\left[\mathrm{Ca}^{2+}\right]_{i}$ increase can trigger various short- and long-term events, such as neurotransmitter release, synaptic plasticity, cell growth, survival, and death (Ghosh and Greenberg, 1995). It has

\footnotetext{
Received Sept. 18, 1996; revised Nov. 8, 1996; accepted Dec. 4, 1996.

We are grateful to Dr. Alan Aderem for the anti-MARCKS antiserum and to Dr. Rory Curtis for the anti-GAP-43 antiserum.

Correspondence should be addressed to Dr. Vittorio Gallo, Laboratory of Cellular and Molecular Neurophysiology, National Institute of Child Health and Human Development, National Institutes of Health, Building 49, Room 5A78, 49 Convent Drive, Bethesda, MD 20892-4495.

Mario Pende's present address: Friedrich Miescher Institut, P.O. Box 2543, CH4002 Basel, Switzerland.

Copyright (C) 1997 Society for Neuroscience $\quad 0270-6474 / 97 / 171291-11 \$ 05.00 / 0$
}

been proposed that $\mathrm{Ca}^{2+}$ signals induce long-term cellular responses by regulating the function of several transcription factors, thus leading to new gene expression. In particular, analysis of heterologous gene promoters has indicated that cAMP response element binding protein $(\mathrm{CREB})$ is a critical mediator of $\mathrm{Ca}^{2+}$ dependent gene expression (Sheng et al., 1990). CREB constitutively binds to a short sequence in the promoter of several genes, the $\mathrm{Ca}^{2+} / \mathrm{cAMP}$ response element (CaRE/CRE). $\mathrm{Ca}^{2+}$, as well as cAMP and growth factor signals, activates CREB and promotes CRE-dependent transcription by inducing CREB phosphorylation at a specific amino acid residue, Serine-133 (Ser-133) (Sheng et al., 1991). CREB becomes phosphorylated during some forms of synaptic activity (Deisseroth et al., 1996) and is required for several learning processes and adaptive responses in the brain (Bourtchuladze et al., 1994; Maldonado et al., 1996).

Because of the complexity of $\mathrm{Ca}^{2+}$ signal transduction, it is still unclear how $\mathrm{Ca}^{2+}$ signals are propagated to the nucleus to regulate CREB Ser-133 phosphorylation. $\mathrm{Ca}^{2+}$ directly influences the activity of many key regulatory enzymes, such as $\mathrm{Ca}^{2+}$. calmodulin-dependent kinases (CaMKs), protein kinase $\mathrm{C}(\mathrm{PKC})$, and $\mathrm{Ca}^{2+}$-calmodulin-dependent adenylate cyclase, which in turn may activate cAMP-dependent protein kinase (PKA). All of these kinases phosphorylate CREB Serine-133 (Ser-133) in vitro (Yamamoto et al., 1988; Sheng et al., 1991). Similar to growth factor signals, $\mathrm{Ca}^{2+}$ can also activate the mitogen-activated protein kinase (MAPK) pathway (Finkbeiner and Greenberg, 1996), 
which involves Ras, raf kinases, MAP kinase kinase (MEK), MAPK, and p90 ribosomal S6 kinase (RSK). The physiological targets of the $\mathrm{Ca}^{2+}$-activated MAPK pathway are still to be identified.

We have analyzed the $\mathrm{Ca}^{2+}$-dependent signal transduction pathways leading to CREB phosphorylation in oligodendrocyte progenitor (OP) cells. OPs can be cultured as a pure and undifferentiated population of cells that maintain the developmental properties displayed in vivo (Dubois-Dalcq and Armstrong, 1992). OP cells co-express membrane receptors for various neurotransmitters and growth factors (Finkbeiner, 1993; Barres and Raff, 1994; Steinhauser and Gallo, 1996), and the role of these extracellular signals in oligodendrocyte development has been studied intensely (Barres and Raff, 1994; Gallo et al., 1996); however, the mechanism by which neurotransmitter and growth factor signals are integrated in these cells is still unclear. In the present study, we show that stimulation of ion channels, G-protein-coupled receptors, and tyrosine kinase receptors in OP cells leads to $\mathrm{Ca}^{2+}$-dependent activation of the MAPK pathway, which can propagate membrane receptor signals to the nucleus by inducing CREB phosphorylation at Ser-133.

\section{MATERIALS AND METHODS}

Materials. Platelet-derived growth factor-AA (PDGF) and basic fibroblast growth factor (bFGF) were purchased from Upstate Biotechnology (Lake Placid, NY). Kainate, carbachol, 12-O-tetradecanoylphorbol-13-acetate (TPA), and forskolin were from Sigma (St. Louis, MO). PD 098059 was from New England Biolabs (Beverly, MA). KN-93 was from Seikagaku America (Ijamsville, MD). The acetoxymethylester of 1,2-bis-(2-aminophenoxy)ethane- $N, N, N^{\prime}, N^{\prime}$-tetra-acetic acid (BAPTA-AM) and fura-2 were from Molecular Probes (Eugene, OR). Anti-MARCKS and antiGAP-43 antibodies were obtained from Alan Aderem (The Rockefeller University, New York, NY) and Rory Curtis (Regeneron Pharmaceuticals, Tarrytown, NY), respectively. Anti-CREB antiserum was purchased from Upstate Biotechnology. Phospho-specific CREB (Ser-133) antiserum (New England Biolabs) is raised against a synthetic phospho-Ser133 peptide corresponding to residues 129 to 137 of human CREB. Phospho-specific MAPK (Tyr204) antiserum (New England Biolabs) is raised against a synthetic phospho-Tyr204 peptide corresponding to residues 196 to 209 of human ERK-1. Anti-calmodulin-dependent kinase (CaMK) II antibodies $\mathrm{CB} \alpha-2$ and $\mathrm{CB} \beta-1$ were from Life Technologies (Gaithersburg, MD). Anti-RSK antiserum was either purchased from Upstate Biotechnology or obtained as described previously (Chen and Blenis, 1990). Anti-Pan PKC antiserum (Upstate Biotechnology) is raised against a C-terminal peptide of PKC $\beta$ II and cross-reacts with PKC $\alpha, \beta \mathrm{I}$, $\gamma$, and $\delta$ isozymes; its cross-reactivity with the atypical isoforms of PKC was not tested. Anti-v-H-Ras antibody Ab-1 (Oncogene Science, Cambridge, MA) reacts with $\mathrm{H}-, \mathrm{K}-$ and N-Ras proteins. Anti-p70 S6 $\left(\mathrm{p} 70^{\mathrm{S} 6 \mathrm{~K}}\right)$ kinase antiserum is raised against the $\mathrm{C}$-terminal region of the protein (Chung et al., 1992).

Cell culture and stimulation. Cortical OP cells were prepared from embryonic day 20 Sprague Dawley rats as described previously (Patneau et al., 1994; Gallo and Armstrong, 1995). Cells were grown for 2-4 d on polyornithine-coated plastic dishes (for biochemical experiments) or glass coverslips (for calcium-imaging experiments) in DMEM (Life Technologies)-N1 supplemented with 30\% B-104 neuroblastoma cellconditioned medium (Louis et al., 1992). The OP cultures contained $>95 \%$ of LB1(anti-GD3)-positive cells, and $\sim 3 \%$ of O4-positive prooligodendroblast (Gallo and Armstrong, 1995; Gallo et al., 1996). The culture medium was removed from OP cell cultures and replaced with DMEM 4-5 hr before stimulation. Stimulating agents and kinase inhibitors were added directly to the cell culture medium.

Calcium measurements. OP cells were incubated with $5 \mu \mathrm{M}$ fura-2 AM for $20 \mathrm{~min}$ at room temperature, as described previously (Fatatis and Russell, 1992). $\mathrm{Ca}^{2+}$-imaging experiments were performed as described previously (Yagodin et al., 1994).

Immunoblot analysis. After incubation with stimulating agents for the indicated periods of time, cells were washed twice with PBS, and total cell extracts were prepared as described by Ginty et al. (1993). OP cells $\left(5-7 \times 10^{5}\right.$ cells in $35 \mathrm{~mm}$ plates) were lysed in $0.1 \mathrm{ml}$ of boiling sample buffer $(62.5 \mathrm{~mm}$ Tris, $\mathrm{pH} \quad 6.8, \quad 1 \%$ SDS, $10 \%$ glycerol, 5\% 2-mercaptoethanol), and boiled for $5 \mathrm{~min}$. Protein extracts were electrophoresed on $10 \%$ polyacrylamide gels and transferred to Immobilion membranes (Millipore, Marlborough, MA). Blots were blocked with 4\% BSA (Miles, Kankakee, IL) in a buffer containing $10 \mathrm{~mm}$ Tris, pH 7.4, 150 $\mathrm{mm} \mathrm{NaCl}$, and $0.05 \%$ Tween 20 (TBST) for $1 \mathrm{hr}$ at room temperature, and then incubated overnight at $4^{\circ} \mathrm{C}$ with either anti-P-CREB (1:2000), anti-P-MAPK (1:2000), anti-RSK (Upstate Biotechnology; $2 \mu \mathrm{g} / \mathrm{ml}$ ), or anti-Pan-PKC $(1 \mu \mathrm{g} / \mathrm{ml})$ antisera in TBST with $4 \%$ BSA. Immunoreactivity was visualized by chemiluminescence detection systems (ECL, Amersham, Arlington Heights, IL, or Phototope-Star, New England Biolabs). Films were scanned, and immunoreactivity was determined by densitometry (Microtek ScanWizard Plug-In, Redondo Beach, CA).

Cell labeling and immunoprecipitation. After a $2 \mathrm{hr}$ starvation in DMEM, OP cells $\left(2-3 \times 10^{6}\right.$ cells in $60 \mathrm{~mm}$ tissue culture plates) were incubated for $1 \mathrm{hr}$ in phosphate-free DMEM and then metabolically labeled with $\left[{ }^{32} \mathrm{P}\right]$-orthophosphate (DuPont NEN, Boston, MA) $(200 \mu \mathrm{Ci}$ in $1.5 \mathrm{ml}$ of phosphate-free medium) for $2 \mathrm{hr}$ before stimulation. After treatment, cells were collected in $0.5 \mathrm{ml}$ of cold RIPA buffer $(10 \mathrm{~mm}$ sodium phosphate, pH 7.2, $150 \mathrm{~mm} \mathrm{NaCl}, 1 \mathrm{~mm}$ EGTA, $50 \mathrm{~mm} \mathrm{NaF}, 1 \%$ NP- $40,1 \%$ sodium deoxycholate, $0.1 \%$ SDS, 1 mM [4-(2-aminoethyl)benzenesulfonylfluoride hydrochloride], $10 \mu \mathrm{g} / \mathrm{ml}$ leupeptin, $10 \mu \mathrm{g} / \mathrm{ml}$ aprotinin) and drawn 10 times through a 0.22 gauge needle. Lysates were centrifuged at $40,000 \times g$ for $15 \mathrm{~min}$ at $4^{\circ} \mathrm{C}$, and supernatants were incubated for $1 \mathrm{hr}$ at $4^{\circ} \mathrm{C}$ with either anti-MARCKS $(2 \mu \mathrm{l} /$ tube $)$, antiGAP-43 antiserum ( $5 \mu \mathrm{l} /$ tube), or the combination of CB- $\beta$ - 1 (1 $\mu \mathrm{l} /$ tube) and CB- $\alpha-2(2 \mu \mathrm{l} /$ tube $)$ subunit-specific anti-CaMK II antibodies. Immune complexes were isolated using protein A Sepharose beads $(50 \mu$; Zymed, San Francisco, CA). Immunoprecipitates were washed twice with buffer A (10 mm Tris, pH 8, $500 \mathrm{~mm} \mathrm{NaCl}, 0.5 \%$ NP-40, 0.05\% SDS), once with buffer B (10 mM Tris, $\mathrm{pH} 8,150 \mathrm{~mm} \mathrm{NaCl}, 0.5 \% \mathrm{NP}-40,0.05 \%$ SDS, $0.5 \%$ sodium deoxycholate), once with buffer C (10 mM Tris, $\mathrm{pH} 8$, $0.05 \%$ SDS), solubilized in boiling SDS sample buffer for $5 \mathrm{~min}$, and resolved on SDS polyacrylamide gels. Phosphoprotein levels were detected by autoradiography and quantified by using PhosphorImager (Molecular Dynamics, Sunnyvale, CA).

Determination of Ras GTP/GDP ratio. OP cells $\left(4 \times 10^{6}\right.$ cells in $100 \mathrm{~mm}$ tissue-culture plates) were starved in N1 medium for $1 \mathrm{~d}$ and then labeled metabolically with $\left[{ }^{32} \mathrm{P}\right]$-orthophosphate (DuPont NEN; $500 \mu \mathrm{Ci}$ in $3 \mathrm{ml}$ of phosphate-free DMEM) for $4 \mathrm{hr}$. After treatment with stimulating agents, cells were lysed in $0.5 \mathrm{ml}$ of a buffer containing $20 \mathrm{~mm}$ Tris, $\mathrm{pH}$ $7.4,150 \mathrm{~mm} \mathrm{NaCl}, 1 \mathrm{mM} \mathrm{MgCl} 2,1 \%$ Triton X-100, and $2 \mu \mathrm{g} / \mathrm{ml}$ of anti-Ras antibody. Ras immunoprecipitation and GTP loading assays were performed essentially as described in Rosen et al. (1994).

Radiolabeled phorbol ester binding assay. OP cells $\left(5 \times 10^{5}\right.$ cells in 35 $\mathrm{mm}$ tissue-culture plates) were washed once with a balanced salt solution (BSS) (160 mM NaCl, $2.5 \mathrm{~mm} \mathrm{KCl,} 2 \mathrm{~mm} \mathrm{CaCl}_{2}, 2 \mathrm{~mm} \mathrm{MgCl}_{2}, 10 \mathrm{~mm}$ HEPES, pH 7.4, $10 \mathrm{~mm}$ glucose, $0.1 \%$ fatty acid-free BSA), and incubated at $20^{\circ} \mathrm{C}$ for $10 \mathrm{~min}$ in $1 \mathrm{ml}$ of BSS containing the designated treatment, and $1 \mathrm{~nm}$ phorbol-12,13-dibutyrate $\left(\left[{ }^{3} \mathrm{H}\right]-\mathrm{PDBu}, 20 \mathrm{Ci} / \mathrm{mmol}\right.$, DuPont NEN) (Vaccarino et al., 1991). Nonspecific binding was determined by adding $1 \mu \mathrm{M}$ TPA to the incubation medium. In the $\mathrm{Ca}^{2+}$-free medium, $\mathrm{CaCl}_{2}$ was omitted from the BSS. Cells were then washed rapidly with ice-cold BSS and lysed with $0.1 \mathrm{M} \mathrm{NaOH}$. Aliquots of the extracts were used for protein determination and liquid scintillation counting.

cAMP and kinase assays. Kinase assays for RSK and $\mathrm{p} 70^{\mathrm{S} 6 \mathrm{~K}}$ kinase were performed as described previously (Chen and Blenis, 1990), using GST-S6 as a substrate (Fisher and Blenis, 1996). cAMP levels were assayed as directed by kit manufacturers (Amersham).

\section{RESULTS}

\section{CREB Ser-133 phosphorylation by extracellular signals}

CREB nuclear factor is constitutively expressed in cells of the oligodendrocyte lineage (Sato-Bigbee and Yu, 1993) (M. Pende and V. Gallo, unpublished data). We examined whether extracellular signals trigger CREB Ser-133 phosphorylation in OP cells, an event necessary for the transcriptional activating function of this protein (Gonzalez and Montminy, 1989). OP cells were treated with various stimulating agents, and cell extracts were immunoblotted with a phospho-specific antiserum (anti-PCREB), which recognizes the $43 \mathrm{kDa}$ CREB protein only when the Ser-133 amino acid residue is phosphorylated (Ginty et al., 


\section{time of incubation (min)}

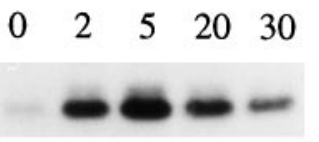

KAINATE

$\begin{array}{llll}0 & 5 & 10 & 30\end{array}$

\section{CARBACHOL}

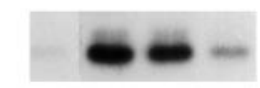

$\begin{array}{lll}0 & 5 & 15\end{array}$

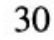

PDGF
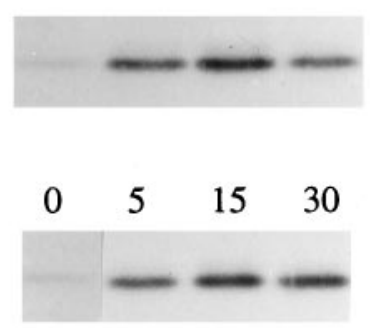

bFGF

$\begin{array}{llll}0 & 5 & 30 & 60\end{array}$

\section{FORSKOLIN}

Figure 1. Activation of ligand-gated channels, G-protein-coupled and growth factor receptors in OP cells causes CREB phosphorylation with a different temporal pattern. Immunoblot analysis with an anti-P-CREB antiserum of extracts from OP cells incubated for the indicated periods of time with $300 \mu \mathrm{M}$ kainate, $300 \mu \mathrm{M}$ carbachol, $10 \mathrm{ng} / \mathrm{ml}$ PDGF, $10 \mathrm{ng} / \mathrm{ml}$ $\mathrm{bFGF}$, and $50 \mu \mathrm{M}$ forskolin.

1993). When OP cells were incubated for various periods of time with the non-NMDA glutamate receptor agonist kainate, the cholinergic agonist carbachol, or the growth factors bFGF and PDGF, a significant stimulation of CREB Ser-133 phosphorylation was observed (Fig. 1). Direct activation of PKC by the phorbol ester TPA also triggered a sustained CREB phosphorylation (data not shown), whereas increase of cAMP levels by forskolin led to only a moderate induction (Fig. 1). The effect of carbachol on CREB phosphorylation was found to be mediated by G-protein-coupled muscarinic receptors, because it was mimicked by subtype-selective agonist methacholine and was antagonized by atropine (data not shown). Immunoblot analysis with an antiCREB antiserum that recognizes both the phosphorylated and unphosphorylated forms of CREB showed no change in total CREB protein levels after incubation with stimulating agents (data not shown).

Analysis of the kinetics of CREB phosphorylation in response to different stimuli indicated that kainate and carbachol elicited a rapid and transient phosphorylation of the nuclear factor, which peaked $5 \mathrm{~min}$ after receptor activation and then declined toward basal levels. In contrast, responses to the growth factors PDGF and bFGF displayed a slower onset, remaining constant for at least $30 \mathrm{~min}$ in the case of bFGF, and decreasing after $15 \mathrm{~min}$ in the case of PDGF. Moreover, the effects of PDGF and bFGF were not additive (data not shown), suggesting that the two growth factors lead to CREB phosphorylation through a common intracellular pathway. Taken together, these results indicate that in OP cells, as observed in other systems, the transcription factor CREB is a nuclear target for multiple signaling pathways that are initiated by activation of ion channels, as well as G-proteincoupled and tyrosine kinase receptors. The distinct kinetics of CREB phosphorylation in response to neurotransmitters and growth factors may account for differential regulation of gene expression by these two classes of extracellular signals.

\section{Effect of kainate, carbachol, and bFGF on $\left[\mathrm{Ca}^{2+}\right]_{\mathbf{i}}$}

We next asked at what level kainate, carbachol, and growth factor signaling pathways converge in OP cells to produce identical nuclear responses, i.e., CREB Ser-133 phosphorylation. Because all of these stimuli are known to alter $\mathrm{Ca}^{2+}$ homeostasis in OP cells (Hart et al., 1989; Cohen and Almazan, 1994; Holtzclaw et al., 1995; Meucci et al., 1996), we reasoned that $\mathrm{Ca}^{2+}$ might be a common second messenger necessary for signal transduction to the nucleus. Fura-2-based $\mathrm{Ca}^{2+}$ imaging experiments showed that stimulation of OP cells with kainate, carbachol, or bFGF produced intracellular $\mathrm{Ca}^{2+}$ responses that differed in amplitude and time course. Incubation of OP cells for $5 \mathrm{~min}$ with kainate elicited a large and persisting rise in $\left[\mathrm{Ca}^{2+}\right]_{\mathrm{i}}$ (Fig. $2 A$ ). This was caused by transmembrane $\mathrm{Ca}^{2+}$ influx, because it was prevented by removal of $\mathrm{Ca}^{2+}$ from the extracellular solution (Fig. $2 A$ ) and is mainly attributable to $\mathrm{Ca}^{2+}$ flowing through the kainate-gated ion channel itself (Fulton et al., 1992; Pende et al., 1994; Puchalski et al., 1994; Meucci et al., 1996). Cells treated with carbachol showed a transient $\left[\mathrm{Ca}^{2+}\right]_{\mathrm{i}}$ peak elevation followed by a sustained plateau that lasted during the entire period of agonist application (Fig. $2 B)$. The peak phase was evoked either in normal external $\left[\mathrm{Ca}^{2+}\right]$ $(1.5 \mathrm{~mm})$ or in nominally $\mathrm{Ca}^{2+}$-free medium and therefore was attributable to $\mathrm{Ca}^{2+}$ release from intracellular stores (Simpson et al., 1995). Conversely, the plateau component was absent when carbachol-stimulated cells were perfused in a $\mathrm{Ca}^{2+}$-free solution (Fig. $2 B$ ), indicative of a capacitative $\mathrm{Ca}^{2+}$ entry across the plasma membrane (Clapham, 1996) (P. Simpson and J. Russell, unpublished data). Finally, $\left[\mathrm{Ca}^{2+}\right]_{\mathrm{i}}$ increases in response to bFGF, alone or in combination with PDGF, were characterized by slow kinetics and extremely low amplitude (filled circles in Fig. $2 C$ represent one of the largest $\mathrm{Ca}^{2+}$ responses to the growth factor). Although the majority of cells responded to kainate and carbachol ( $>95 \% ; n=53$ for kainate, $n=33$ for carbachol), a rise in $\left[\mathrm{Ca}^{2+}\right]_{\mathrm{i}}$ during bFGF exposure was detectable in only $22 \%$ of the cells analyzed $(n=119)$. Treatment of OP cells with bFGF in the absence of extracellular $\mathrm{Ca}^{2+}$ also evoked a response in only a small percentage of cells $(16 \%, n=100$; Fig. $2 C$ shows a recording from a cell that did not respond to bFGF in the absence of external $\mathrm{Ca}^{2+}$ ).

To abolish agonist-evoked increases in intracellular $\mathrm{Ca}^{2+}$ levels (because of either $\mathrm{Ca}^{2+}$ release from intracellular stores or influx of the cation across the plasma membrane), we exposed OP cells to BAPTA, a very effective $\mathrm{Ca}^{2+}$ chelator (Tsien, 1980). Figure 2 shows that preincubation of OP cells for $45 \mathrm{~min}$ with the membrane-permeant BAPTA-AM strongly attenuated $\mathrm{Ca}^{2+}$ transients in response to kainate, carbachol, and bFGF, thus providing an effective tool for understanding the role of intracellular $\mathrm{Ca}^{2+}$ in signal transduction in OP cells (see below).

\section{$\mathrm{Ca}^{2+}$-dependence of CREB phosphorylation}

We next studied whether interfering with intracellular $\mathrm{Ca}^{2+}$ transients affected the induction of CREB phosphorylation by neurotransmitters and growth factors. The omission of $\mathrm{Ca}^{2+}$ ions from 
A
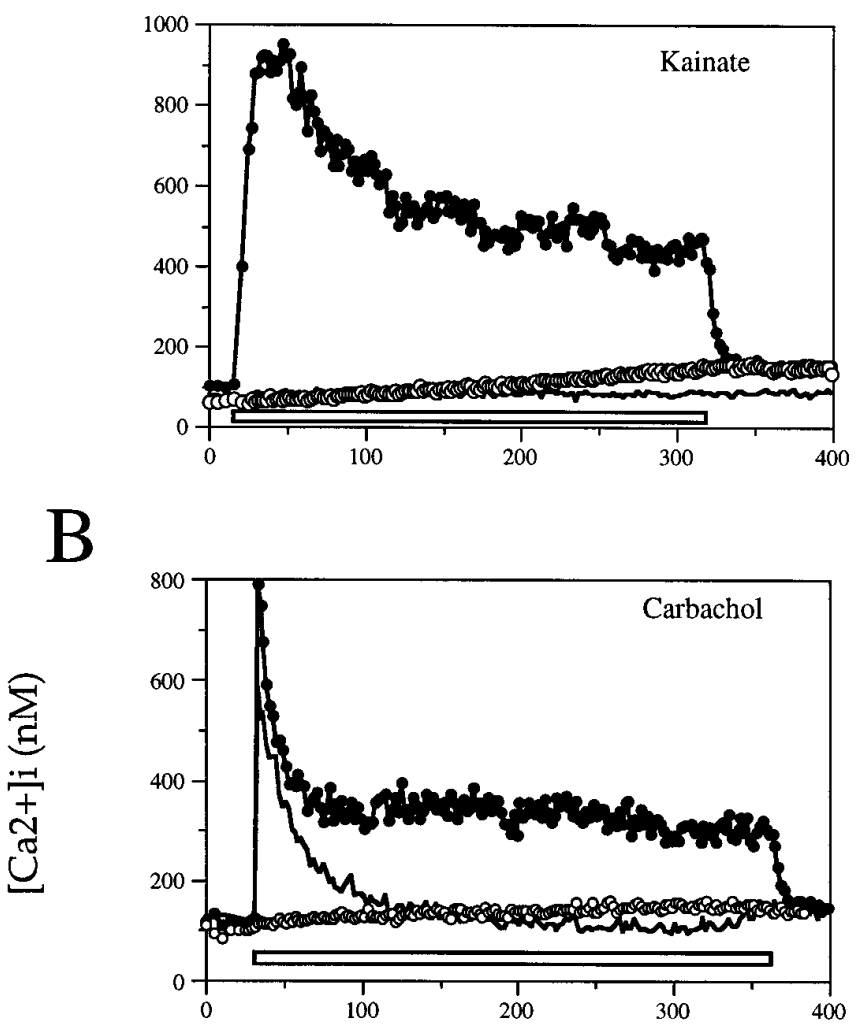

C

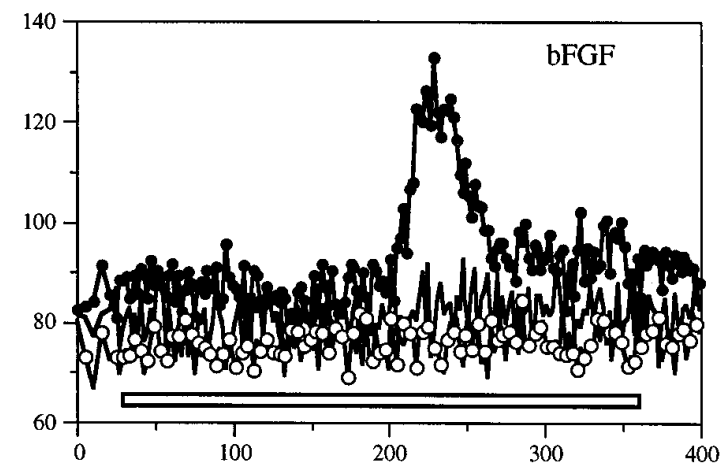

Time (seconds)

Figure 2. Fura-2 measurements of intracellular $\mathrm{Ca}^{2+}$ levels in response to kainate, carbachol, and bFGF. Representative traces recorded from individual OP cells during perfusion with $300 \mu \mathrm{M}$ kainate $(A), 300 \mu \mathrm{M}$ carbachol $(B)$, and $10 \mathrm{ng} / \mathrm{ml}$ bFGF $(C)$. The period of agonist application ( $5 \mathrm{~min}$ ) is indicated by the bar at the bottom of the traces. Incubation of OP cells with bFGF for a longer period of time $(9 \mathrm{~min})$ did not result in an increase in the percentage of responding cells $(14 \% ; n=63)$. OP cells were incubated with the stimulating agents in the presence of $1.5 \mathrm{~mm}$ extracellular $\mathrm{Ca}^{2+}$ ( filled circles), in nominally $\mathrm{Ca}^{2+}$-free buffer (no symbols), or in a $\mathrm{Ca}^{2+}$-containing buffer in the presence of $45 \mu \mathrm{M}$ BAPTA-AM (open circles). Cells were treated with BAPTA-AM for $45 \mathrm{~min}$ before stimulation.

the extracellular medium completely abolished kainate-induced CREB phosphorylation (Fig. 3). The effect of carbachol was also strongly attenuated in the absence of extracellular $\mathrm{Ca}^{2+}$, indicating that capacitative $\mathrm{Ca}^{2+}$ entry across the membrane is the major trigger of the signaling pathway leading to CREB phosphorylation

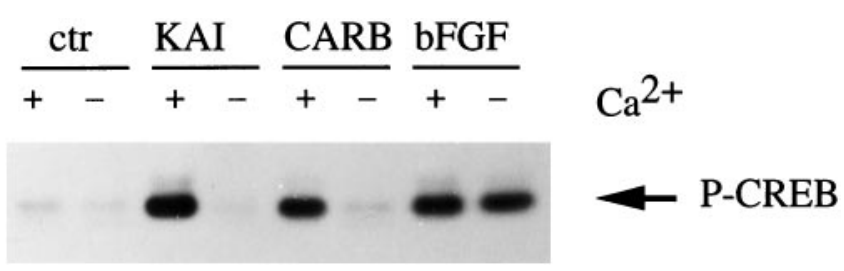

Figure 3. The effect of kainate and carbachol on CREB phosphorylation requires transmembrane influx of extracellular $\mathrm{Ca}^{2+}$. Immunoblot analysis with an anti-P-CREB antiserum of extracts from OP cells treated as indicated (KAI: $300 \mu \mathrm{M}$ kainate for $5 \mathrm{~min}$; $C A R B: 300 \mu \mathrm{M}$ carbachol for 5 $\mathrm{min} ; b F G F: 10 \mathrm{ng} / \mathrm{ml} \mathrm{bFGF}$ for $15 \mathrm{~min}$ ). Cells were incubated with the stimulating agents in a balanced salt solution containing $160 \mathrm{~mm} \mathrm{NaCl}, 2.5$ $\mathrm{mM} \mathrm{KCl}, 2 \mathrm{~mm} \mathrm{MgCl} 2,10 \mathrm{~mm}$ HEPES, and $10 \mathrm{~mm}$ glucose, in the presence (+lanes) or in the absence (- lanes) of $2 \mathrm{~mm} \mathrm{CaCl}_{2}$. The $43 \mathrm{kDa}$ CREB phosphoprotein is indicated by the arrow.

on muscarinic receptor activation (Fig. 3). The effect of bFGF was not influenced by the absence of extracellular $\mathrm{Ca}^{2+}$ (Fig. 3); however, chelation of intracellular $\mathrm{Ca}^{2+}$ by BAPTA not only reduced kainate- and carbachol-evoked CREB phosphorylation, it also inhibited growth factor signaling to CREB (Fig. $4 A$ ). These results suggest that the kainate-, carbachol-, and growth factoractivated pathways leading to CREB phosphorylation are all regulated, to some extent, by intracellular $\mathrm{Ca}^{2+}$.

\section{Activation of putative CREB kinases in OP cells}

To investigate the $\mathrm{Ca}^{2+}$-dependent pathways linking receptor activation with phosphorylation of the nuclear factor CREB, we assayed the activity of putative CREB kinases (PKA: Yamamoto et al., 1988; CaMK: Sheng et al., 1990; PKC: Yamamoto et al., 1988 and de Groot et al., 1993; RSK: Böhm et al., 1995 and Xing et al., 1996; p70 ${ }^{\mathrm{S} 6 \mathrm{~K}}$ : de Groot et al., 1994) in OP cells treated with kainate, carbachol, and growth factors.

First, we measured CaMK II autophosphorylation, which has been shown to accompany enzyme activation in different systems (McNicol et al., 1990; Bading et al., 1993). Figure 5A shows that kainate and carbachol stimulated ${ }^{32} \mathrm{P}$ incorporation into CaMK II. The effect of kainate was rapid and transient, reaching a maximum within 2 min (3.2-fold increase; $n=5)$. In contrast, stimulation with TPA and growth factors did not lead to CaMK activation (Fig. 5A, and data not shown).

To analyze PKC activation, we measured the in vivo phosphorylation of two well characterized PKC-specific substrates: the myristoylated alanine-rich $C$ kinase substrate MARCKS (Aderem, 1992) and the growth-associated protein GAP-43 (Skene, 1989). Both proteins were found to be phosphorylated shortly after stimulation with kainate, carbachol, and the PKC activator TPA (Fig. 5B, and data not shown). In particular, kainate caused a 2.9-fold stimulation of PKC activity (measured as MARCKS phosphorylation; $n=2$ ) within $2 \mathrm{~min}$ of incubation. Exposure to the combination of PDGF and bFGF produced only a moderate and steady increase in MARCKS phosphorylation (Fig. 5B). Kainate and carbachol, but not growth factors, also induced PKC translocation to the membrane, as assayed by binding of radiolabeled phorbol esters to cultured OP cells (data not shown). These data indicate further that stimulation of glutamate and acetylcholine receptors in OP cells results in PKC activation.

We next examined the activation of RSK that has been proposed recently to mediate CREB phosphorylation in response to mitogenic signals (Böhm et al., 1995; Xing et al., 1996). Because RSK is a direct effector of the Ras/MAPK cascade (Blenis, 1993), we analyzed activation of this pathway in OP cells at three distinct 
A

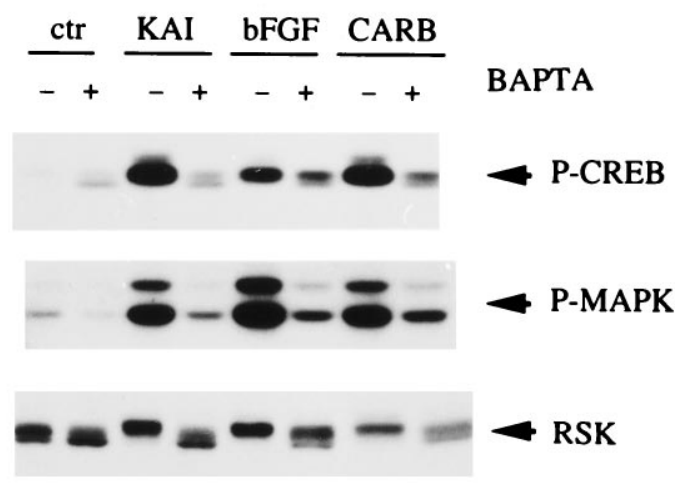

B

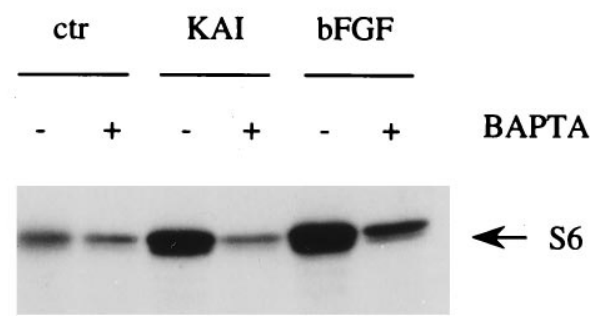

Figure 4. The effects of kainate, carbachol, and growth factors on CREB and on the MAPK/RSK pathway require intracellular $\mathrm{Ca}^{2+} . A$, OP cells were preincubated with DMSO (- lanes) or $60 \mu \mathrm{M}$ BAPTA-AM (+lanes) for $2 \mathrm{hr}$. Cells were then treated with the stimulating agents as indicated (KAI: $300 \mu \mathrm{M}$ kainate for $5 \mathrm{~min}$; $C A R B: 300 \mu \mathrm{M}$ carbachol for $5 \mathrm{~min}$; $b F G F: 10 \mathrm{ng} / \mathrm{ml} \mathrm{bFGF}$ for $15 \mathrm{~min})$. Aliquots of the same cell extracts were sequentially immunoblotted with anti-P-CREB, anti-P-MAPK, and antiRSK antisera. The $43 \mathrm{kDa}$ CREB phosphoprotein $(P-C R E B)$, the 44 and $42 \mathrm{kDa}$ ERK-1 and ERK-2 phosphoproteins $(P-M A P K)$, and the $R S K$ protein are indicated by the arrows. Note the mobility shift of RSK (kainate, carbachol, and bFGF lanes in the absence of BAPTA), attributable to hyperphosphorylation. $B$, Effect of BAPTA on kainate- and bFGF-induced RSK activity. OP cells were preincubated with DMSO (lanes) or $45 \mu \mathrm{M}$ BAPTA-AM (+ lanes) for $90 \mathrm{~min}$. Cells then were treated with the stimulating agents as indicated (KAI: $300 \mu \mathrm{M}$ kainate for $5 \mathrm{~min}$; $b F G F: 10 \mathrm{ng} / \mathrm{ml}$ bFGF for $15 \mathrm{~min}$ ). Cell extracts were immunoprecipitated with anti-RSK antiserum, and RSK activity in the immune complex was determined using GST-S6 fusion protein as a substrate. Incorporation of phosphate into S6 was detected by autoradiography after SDS-PAGE analysis. GST-S6 phosphoprotein is indicated by the arrow.

levels: (1) GTP binding to Ras, (2) dual phosphorylation of MAP kinases ERK-1 and ERK-2, and (3) RSK phosphorylation and kinase activity. The results in Figure $6 A$ indicate that the proportion of GTP-bound, active Ras was increased significantly only by treatment with the growth factors PDGF and bFGF, and not by kainate, carbachol, or TPA. When MAPK tyrosine phosphorylation was assessed by immunoblot analysis with phospho-specific antibodies, however, all of these signals appeared to stimulate ERK-1 and ERK-2 (Fig. 4B, and data not shown). The effects of kainate and carbachol on MAPK were more transient than those of growth factors and required influx of extracellular $\mathrm{Ca}^{2+}$ (Fig. $6 B$, and data not shown).

RSK activity in stimulated OP cells was assayed by immunoprecipitation with anti-RSK antibody, combined to in vitro kinase assays, using S6 protein as a substrate. Kainate, carbachol, TPA, and growth factors significantly stimulated RSK activity (Fig. 6C, and data not shown). In support of these functional data, we also observed a reduction of RSK electrophoretic mobility in cells treated with these stimulating agents, as detected by immunoblot analysis with anti-RSK antibodies (Fig. 6D, and data not shown). These slower migrating bands represent hyperphosphorylated forms of RSK, which are likely to be catalytically active (Vik et al., 1990). Incubation with BAPTA-AM clearly reduced MAPK and RSK activation in resting cells, as well as in cells stimulated with kainate, carbachol, and bFGF (Fig. 4A), indicating that the activity of the MAPK/RSK pathway in OP cells is dependent on intracellular $\mathrm{Ca}^{2+}$.

We next examined activation of $\mathrm{p} 70^{\mathrm{S} 6 \mathrm{~K}}$ by immune complex-S6 protein kinase assays and immunoblot analysis in OP cells. Kainate caused only a slight retardation in the electrophoretic mobility of $\mathrm{p} 70^{\mathrm{S} 6 \mathrm{~K}}$, without any detectable change in kinase activity (data not shown), indicating that kainate-stimulated $\mathrm{p} 70^{\mathrm{S} 6 \mathrm{~K}}$ phosphorylation is not sufficient to activate the enzyme. In contrast, growth factors stimulated both $\mathrm{p} 70^{\mathrm{S} 6 \mathrm{~K}}$ phosphorylation and activation (data not shown).

The involvement of PKA in kainate-, carbachol-, and growth factor-induced CREB phosphorylation was ruled out on the basis of two distinct observations. First, none of these agonists significantly increased cAMP levels in OP cells (data not shown). Second, treatment with forskolin $(50 \mu \mathrm{M})$, which caused an 11-fold increase in cAMP levels (data not shown) and likely full activation of PKA, resulted in a weaker induction of CREB phosphorylation as compared with kainate, carbachol, and growth factors (Fig. 1).

In conclusion, our biochemical screening for inducible kinase activity indicates that in OP cells CaMK and PKC are preferentially stimulated by $\mathrm{Ca}^{2+}$ influx, and $\mathrm{p} 70^{\mathrm{S} 6 \mathrm{~K}}$ exclusively by growth factors, whereas RSK is the only potential CREB kinase whose activity is substantially enhanced by both types of signals.

\section{Specific block of the MAPK pathway inhibits CREB phosphorylation induced by calcium influx, growth factors, and TPA}

To elucidate the individual contribution of intracellular pathways in signaling to CREB, various kinase inhibitors were tested for their potency and specificity on the distinct intracellular pathways described above. PD 098059 has recently been characterized as a selective inhibitor of the MAPK pathway (Alessi et al., 1995; Dudley et al., 1995). This compound was found to specifically inhibit MEK, the protein kinase that phosphorylates and activates MAP kinase (Alessi et al., 1995). To test whether PD 098059 was also effective in our system, OP cells were incubated for $1 \mathrm{hr}$ with PD 098059 before stimulation, and then MAPK and RSK phosphorylation were assayed in cell extracts by immunoblot analysis. PD 098059 inhibited basal as well as kainate-, TPA-, and bFGFinduced MAPK phosphorylation (Fig. 7A,B). In particular, $50 \mu \mathrm{M}$ PD 098059 completely suppressed MAPK phosphorylation by kainate but was less effective in counteracting the effects of bFGF and TPA, which are stronger activators of the MAPK pathway. This differential potency of the MEK inhibitor is likely to depend on the strength of the stimulus, as observed previously in other cellular systems (Alessi et al., 1995). In all of the conditions studied, RSK phosphorylation always paralleled MAPK phosphorylation, consistent with the role of RSK as a downstream effector of the MAPK pathway (Fig. 7A,B). As expected, PD 098059 also inhibited the RSK phosphotransferase activity induced by kainate and bFGF (Fig. $7 C$ ).

In the presence of $50 \mu \mathrm{M}$ PD 098059, CREB phosphorylation in 
B

Figure 5. CaMK II and PKC activation in response to kainate and carbachol. $A$, CaMK II autophosphorylation. OP cells were metabolically labeled with $\left[{ }^{32} \mathrm{P}\right]$-orthophosphate before stimulation and treated as indicated (KAI: $300 \mu \mathrm{M}$ kainate for $2 \mathrm{~min}$ unless otherwise indicated; $C A R B: 300 \mu \mathrm{M}$ carbachol for $2 \mathrm{~min}$; TPA: $100 \mathrm{nM}$ TPA for $5 \mathrm{~min}$ ), lysed, and immunoprecipitated with $\alpha$ - and $\beta$-subunit-specific anti-CaMK II antibodies. Incorporation of phosphate into CaMK II was detected by autoradiography after SDS-PAGE analysis. $B$, In vivo phosphorylation of PKC substrates. OP cells were metabolically labeled with $\left[{ }^{32} \mathrm{P}\right]-$ orthophosphate and treated as indicated (KAI: $300 \mu \mathrm{M}$ kainate for various periods of time; TPA: $100 \mathrm{~nm}$ TPA for $5 \mathrm{~min} ; P D G F+$ $b F G F: 10 \mathrm{ng} / \mathrm{ml}$ PDGF $+10 \mathrm{ng} / \mathrm{ml} \mathrm{bFGF}$ for various periods of time), lysed, and immunoprecipitated with anti-MARCKS or antiGAP-43 antisera, followed by SDS-PAGE analysis. Incorporation of phosphate into MARCKS and GAP-43 was detected by autoradiography. The $80 \mathrm{kDa}$ MARCKS and the $43 \mathrm{kDA}$ GAP- 43 phosphoproteins are indicated.

kainate-, TPA-, and bFGF-treated cells was reduced by $\sim 70 \%$ (Fig. $7 A$ ), suggesting that the MAPK pathway mediates, at least in part, $\mathrm{CREB}$ regulation by $\mathrm{Ca}^{2+}$ influx, $\mathrm{PKC}$ activation, and growth factors, respectively. Treatment with the MEK inhibitor did not affect CREB phosphorylation in unstimulated cells or in forskolin-treated cells (Fig. 7), indicating that PD 098059 did not interfere with basal and PKA-mediated regulation of CREB. Moreover, $50 \mu \mathrm{M}$ PD 098059 did not inhibit the phosphorylation of CaMK by kainate (data not shown), demonstrating that its effects on kainate-stimulated CREB phosphorylation were not attributable to a nonspecific inhibition of the CaMK pathway.

Incubation of OP cells with higher concentrations of PD 098059 $(100 \mu \mathrm{M})$ did not lead to a complete inhibition of CREB activation by any of the stimulating agents (Fig. $7 B)(71 \%$ inhibition of kainate-induced CREB phosphorylation, $n=4 ; 87 \%$ inhibition of bFGF-induced CREB phosphorylation, $n=3$ ). The residual bFGF-induced CREB phosphorylation observed in the presence of the MEK inhibitor is likely to be attributable to the incomplete inhibition of the MAPK pathway. So far, we have no evidence that additional pathways are involved in mediating the effect of growth factors on CREB phosphorylation. In fact, it is unlikely that the stimulation of the $\mathrm{p} 70^{\mathrm{S} 6 \mathrm{~K}}$ pathway by bFGF has any role in CREB regulation, because rapamycin, an inhibitor of $\mathrm{p} 70^{\mathrm{S} 6 \mathrm{~K}}$ activation (Chung et al., 1992), suppressed $\mathrm{p} 70^{\mathrm{S} 6 \mathrm{~K}}$ phosphorylation in OP cells without affecting CREB Ser-133 phosphorylation (data not shown).

It is likely that in kainate-treated cells, in which high concentrations of PD 098059 decreased MAPK phosphorylation to un-
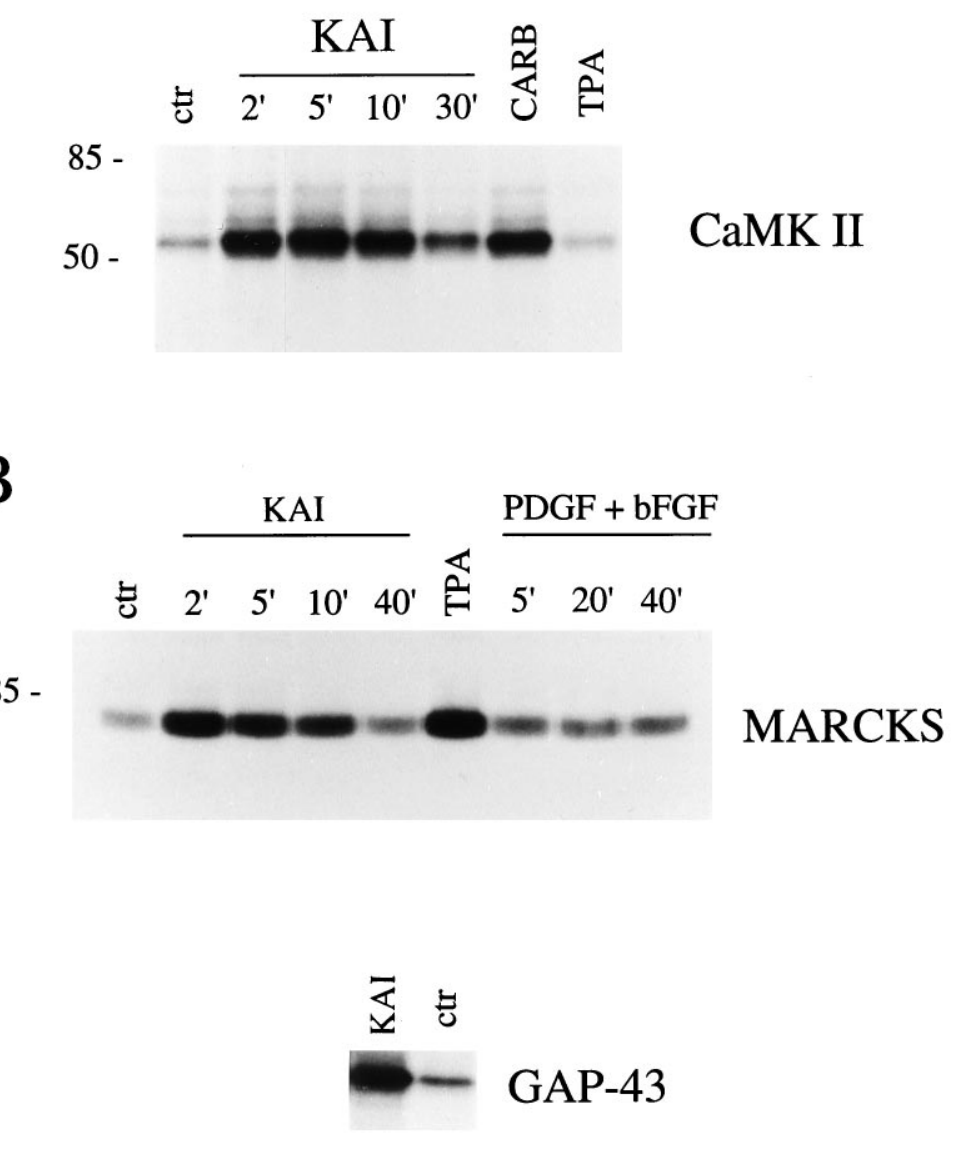

detectable levels (Fig. $7 B$ ), additional $\mathrm{Ca}^{2+}$-activated pathways might contribute to the regulation of CREB phosphorylation. To determine whether activation of CaMK participates in CREB phosphorylation by kainate, we stimulated OP cells in the presence of KN-93, a CaMK inhibitor related to KN-62 (Sumi et al., 1991), which has been used successfully to establish a role for CaMK as mediator of nuclear events in several systems (Bading et al., 1993; Enslen and Soderling, 1994; Deisseroth et al., 1996). Preincubation of the cells with KN-93 significantly inhibited basal and kainate-induced autophosphorylation of CaMK (data not shown), demonstrating that in our conditions KN-93 was effective in blocking the activity of the enzyme. However, when KN-93 was tested for its ability to prevent CREB activation, the CaMK inhibitor caused only a moderate reduction (12\% inhibition, $n=$ 6 ) in the levels of phosphorylated CREB in kainate-treated cells (Fig. $7 B$ ). Induction of CREB phosphorylation by bFGF was not affected by the CaMK inhibitor (Fig. 7B), consistent with our findings that CaMK was not activated by growth factors in these cells.

\section{Role of PKC}

Finally, we examined the role of the $\mathrm{Ca}^{2+}$-dependent conventional PKC isozymes (cPKC) on the induction of CREB phosphorylation by the various stimulating agents. Long-term treatment with TPA strongly decreased the levels of cPKC isoforms (Fig. 8A) and caused a complete inhibition of CREB phosphorylation by TPA and a partial inhibition of CREB phosphorylation by kainate and carbachol (Fig. $8 C$ ). Cells in which cPKC was 
A

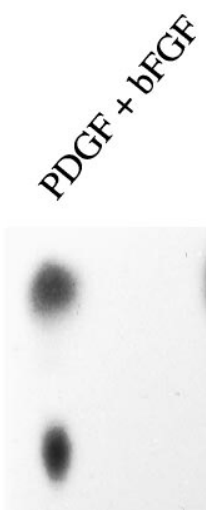

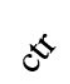

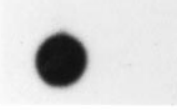

35
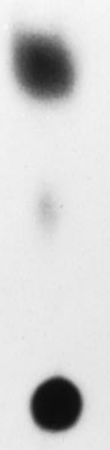

10

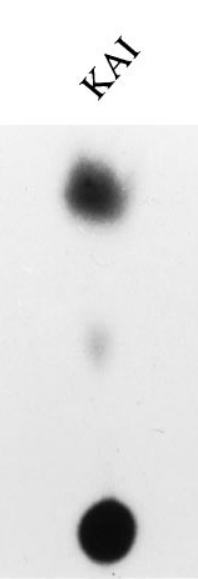

12
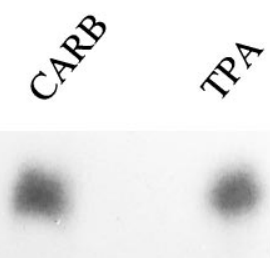

$\bullet$

12

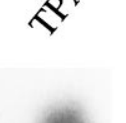

RAS-GDP

RAS-GTP

B

\section{time of incubation ( $\mathrm{min})$}

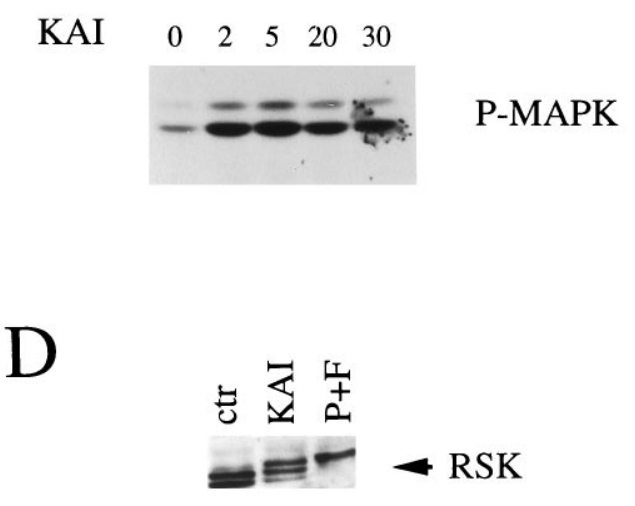

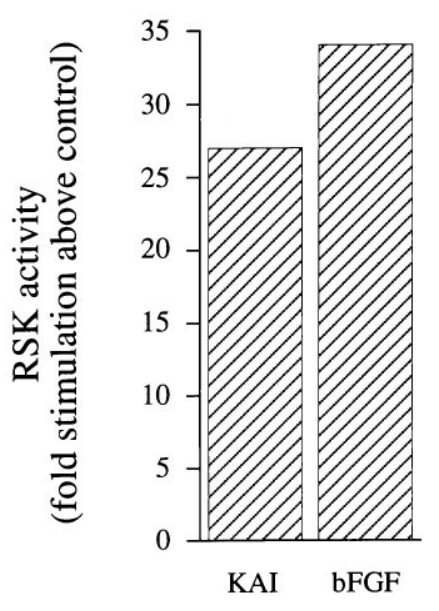

Figure 6. Activation of Ras, MAPK, and RSK by extracellular signals in OP cells. $A$, GDP/GTP binding to Ras in OP cells treated with vehicle (ctr), $300 \mu \mathrm{M}$ kainate for $2 \min (K A I), 300 \mu \mathrm{M}$ carbachol for $2 \min (C A R B), 100 \mathrm{nM} T P A$ for 5 $\mathrm{min}, 10 \mathrm{ng} / \mathrm{ml}$ PDGF $+10 \mathrm{ng} / \mathrm{ml}$ bFGF (PDGF $+b F G F$ ) for $5 \mathrm{~min}$. Cells were metabolically labeled with $\left[{ }^{32} \mathrm{P}\right]$-orthophosphate before stimulation, lysed, and immunoprecipitated with antiRas antibodies. Guanine nucleotides bound to Ras were eluted and separated by thin layer chromatography. Position of GDP and GTP standards is shown. Content of GDP and GTP bound to Ras was quantified by phosphorimager analysis, and the percentage of GTP is indicated at the bottom. B, Time course of MAPK phosphorylation in response to kainate. Immunoblot analysis with an anti-P-MAPK antiserum of extracts from OP cells incubated for the indicated periods of time with $300 \mu \mathrm{M}$ kainate. The 44 and $42 \mathrm{kDa}$ ERK-1 and ERK-2 phosphoproteins ( $P$-MAPK) are indicated. To allow a direct comparison of the kinetics of CREB and MAPK phosphorylation in response to kainate, the immunoblot analysis shown in Figures 1 and $6 B$ was performed on the same cell extracts. Despite some quantitative variability among experiments, the average increase of MAPK phosphorylation after a 5 min stimulation with kainate was $80 \%$ of the increase induced by bFGF $(n=5)$. $C$, Increase of RSK activity in response to kainate and growth factors. OP cells were stimulated with $300 \mu \mathrm{M}$ kainate for $5 \mathrm{~min}$ or with $10 \mathrm{ng} / \mathrm{ml} \mathrm{bFGF}$ for $15 \mathrm{~min}$. RSK activity was determined by immune complex kinase assay using S6 ribosomal protein as substrate. Data presented in the histogram are from one representative experiment and were confirmed in three other independent experiments. $D$, RSK mobility shift in response to kainate and growth factors. Cells were stimulated as indicated (KAI: $300 \mu \mathrm{M}$ kainate for $5 \mathrm{~min} ; P+F: 10 \mathrm{ng} / \mathrm{ml} \mathrm{bFGF}+10$ $\mathrm{ng} / \mathrm{ml}$ PDGF for $15 \mathrm{~min}$ ). Immunoblot analysis of RSK was performed using an antiserum directed against the C-terminal peptide of RSK, which recognizes both the phosphorylated (slower migrating) and unphosphorylated (faster migrating) forms of the protein. The $\sim 85 \mathrm{kDa}$ RSK protein is indicated by the arrow. downregulated also showed a reduced activation of MAPK in response to kainate, carbachol, and TPA (Fig. $8 B$, and data not shown), raising the possibility that in OP cells cPKC functions as an upstream regulator of the MAPK/RSK pathway, which in turn leads to CREB Ser-133 phosphorylation. In contrast, downregulation of $\mathrm{cPKC}$ caused a moderate reduction in the levels of phosphorylated MAPK on growth factor stimulation (Fig. 8B) and did not significantly affect the induction of CREB phosphorylation by bFGF and PDGF (Fig. $8 C$ ) (long-term treatment with TPA partially inhibited growth factor-induced CREB phosphorylation in only one of five experiments). We cannot exclude at present the possibility that in OP cells, TPA-insensitive atypical PKC isoforms may be involved in the transduction of growth factor signals to CREB.

\section{DISCUSSION}

We have characterized the molecular events leading to regulation of the transcription factor CREB in a homogeneous population of primary neural cells, highlighting a central role for the MAPK pathway as an intermediary between cell surface receptors and intracellular $\mathrm{Ca}^{2+}$ and CREB phosphorylation. We have shown that in cortical OPs the MAPK pathway is activated in a $\mathrm{Ca}^{2+}$ dependent fashion on stimulation of glutamate receptor channels and G-protein-coupled cholinergic receptors, as well as in response to growth factors. The MAPK pathway therefore can integrate these distinct upstream signals and transduce them to the nucleus, leading to the phosphorylation of CREB at Ser-133, an event necessary for its transcription-activating function.

The mechanism of MAPK activation is likely to be different for the distinct receptor systems analyzed in our study. The signal transduction pathway linking tyrosine kinase receptors with MAPK activation has been studied extensively in many cell types (Marshall, 1995) and includes ligand binding, receptor dimerization and autophosphorylation, and recruitment of Grb2/Sos complexes that activate Ras by inducing its association with GTP. Raf kinases bind Ras - GTP and are activated by several phosphorylation events, which may involve protein kinases such as $\operatorname{PKC} \alpha$, Src, and KSR (Kolch et al., 1993; Downward, 1995; Marais et al., 1995). Raf kinase activation is then followed by sequential phosphorylation and activation of MEK, MAPK, and RSK. Our analysis shows that such a mechanism is likely to operate also in OP 
(n) 


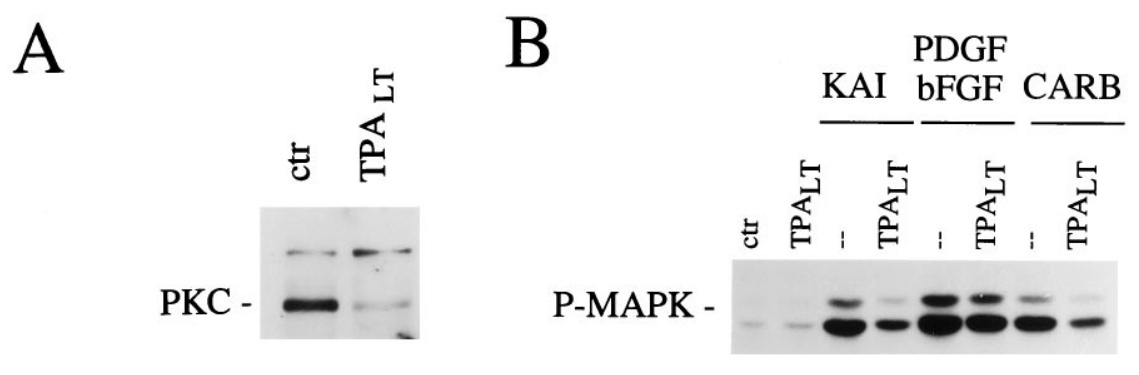

C
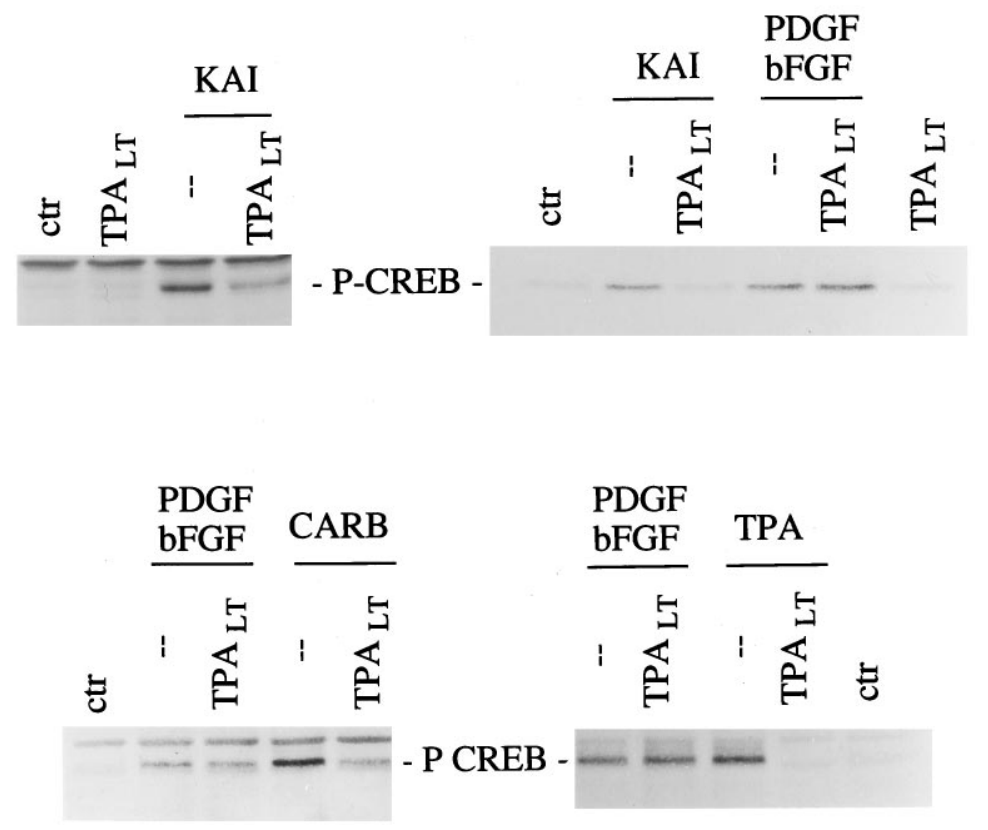

Figure 8. cPKC downregulation inhibits CREB activation by kainate, carbachol, and TPA, without affecting stimulation by growth factors. $A$, Immunoblot analysis with an anti-Pan-PKC antiserum of extracts from OP cells incubated for $10 \mathrm{hr}$ with $0.1 \%$ DMSO (ctr) or $8 \mathrm{~nm}$ TPA $\left(T P A_{L T}\right)$. The $80 \mathrm{kDa}$ PKC isozyme is indicated. $B$ and $C$, OP cells were preincubated with DMSO or $8 \mathrm{nM}$ TPA for $10 \mathrm{hr}\left(T P A_{L T}\right)$, as indicated. Cells were then stimulated with the indicated agonists (KAI: $300 \mu \mathrm{M}$ kainate for $5 \mathrm{~min}$; $C A R B: 300 \mu \mathrm{M}$ carbachol for $5 \mathrm{~min}$; TPA: $100 \mathrm{~nm}$ TPA for $10 \mathrm{~min}$; 10 $\mathrm{ng} / \mathrm{ml} P D G F$ and $b F G F$ for $15 \mathrm{~min})$. Cell extracts were immunoblotted with anti-P-MAPK $(B)$ or anti-PCREB $(C)$ antiserum. The $43 \mathrm{kDa}$ CREB phosphoprotein and the 44 and the $42 \mathrm{kDa}$ ERK-1 and ERK-2 phosphoproteins $(P-M A P K)$ are indicated. ylate and activate Raf in vitro and in vivo through a mechanism that may parallel Raf regulation by Ras and Src (Kolch et al., 1993). Interestingly, we have demonstrated that in OP cells transmembrane $\mathrm{Ca}^{2+}$ influx is sufficient to translocate $\mathrm{PKC}$ to the membrane and to stimulate its catalytic activity (Fig. $5 B$, and data not shown). Moreover, the phorbol ester TPA mimics the effect of kainate and carbachol on PKC stimulation (Fig. $5 B$ ) and leads to MAPK activation without activating Ras (Fig. 6). Finally, downregulation of an $80 \mathrm{kDa}$ PKC isozyme inhibits MAPK activation by $\mathrm{Ca}^{2+}$ influx (Fig. $8 B$ ). Taken together, these observations suggest that PKC may integrate $\mathrm{Ca}^{2+}$ signals in OP cells to activate the MAPK pathway. Additional studies are needed to elucidate whether Ras is involved in MAPK activation by $\mathrm{Ca}^{2+}$ influx in OP cells.

A striking observation in our studies is that the activity of the MAPK pathway is influenced strongly by intracellular $\mathrm{Ca}^{2+}$ levels. Chelation of cytoplasmic $\mathrm{Ca}^{2+}$ by BAPTA inhibits kainate-, carbachol-, and growth factor-induced MAPK and RSK activation (Fig. 4). Although an inhibitory effect of BAPTA on the signal transduction initiated by kainate and carbachol is consistent with its dependence on external $\mathrm{Ca}^{2+}$ (see discussion above), it is surprising that the growth factors also depend on $\mathrm{Ca}^{2+}$ to activate the MAPK pathway. In our culture conditions, bFGF, alone or in combination with PDGF, causes a moderate rise of $\left[\mathrm{Ca}^{2+}\right]_{\mathrm{i}}$ in only $22 \%$ of the OP cells (Fig. 2). This small $\mathrm{Ca}^{2+}$ response is unlikely to account for the strong stimulation of the MAPK pathway by tyrosine kinase signals (for example, see Figs. 4, 6). It is possible, however, that resting levels of $\mathrm{Ca}^{2+}$ are essential as a co-factor for the function of some regulatory elements of the MAPK pathway. This hypothesis is supported by the findings that chelation of cytoplasmic $\mathrm{Ca}^{2+}$ by BAPTA also affects the basal phosphorylation of MAPK and RSK (Fig. 4). Although the $\mathrm{Ca}^{2+}$-dependent step in this phosphorylation cascade has not yet been identified, recent studies have indicated a similar $\mathrm{Ca}^{2+}$-requirement for the function of the MAPK pathway (Burgering et al., 1993; Böhm et al., 1995).

In many cellular systems, activation of the MAPK pathway by growth factors has been implicated in the regulation of gene transcription (Treisman, 1996) and has been associated with the cellular responses of proliferation, differentiation, and transformation (Marshall, 1995). $\mathrm{Ca}^{2+}$-induced activation of MAPK might result in similar biological effects, but only a few studies have analyzed the physiological role of this pathway. Rusanescu et al. (1995), using dominant negative forms of Src and Ras, were able to show that both oncoproteins (probably acting through the MAPK pathway) were necessary to mediate the induction of $N G F I-A$ expression and neurite outgrowth by $\mathrm{Ca}^{2+}$ signals in PC12 cells. These findings demonstrate that $\mathrm{Ca}^{2+}$ and growth factor signals may converge to identical effectors and trigger similar biological processes. In our study in OP cells, we have presented several lines of evidence implicating the MAPK/RSK pathway in the regulation of the transcription factor CREB by 
both $\mathrm{Ca}^{2+}$ influx and growth factors. First, the kinetics of CREB phosphorylation by the two types of signals parallel the kinetics of MAPK phosphorylation (Figs. 1 and 6, and data not shown). Second, CREB, MAPK, and RSK phosphorylation display the same dependence on intracellular $\mathrm{Ca}^{2+}$ (Fig. 4). Third, downregulation of PKC inhibits both MAPK and CREB phosphorylation triggered by $\mathrm{Ca}^{2+}$ influx (Fig. 8). Finally, selective inhibition of the MAPK/RSK pathway by PD 098059 reduces $\mathrm{Ca}^{2+}$ - and growth factor-induced CREB phosphorylation (Fig. 7).

RSK has been shown to phosphorylate CREB Ser-133 in vitro and in vivo on growth factor stimulation (Ginty et al., 1994; Böhm et al., 1995; Xing et al., 1996). Therefore, this enzyme is an excellent candidate for catalyzing the reaction in OP cells; however, other MAPK-activated CREB kinases may also exist in OP cells. Böhm et al. (1995) have reported that some kinases other than RSK were activated by growth factors in melanocytes and displayed CREB kinase activity in vitro.

Initially described as a transcription factor activated by stimuli that raise intracellular levels of cAMP and lead to PKA activation (Gonzalez and Montminy, 1989), CREB was found subsequently to be phosphorylated also at Ser-133 on $\mathrm{Ca}^{2+}$ influx or growth factor stimulation (Sheng et al., 1990; Ginty et al., 1994). Therefore, CREB seems to act as an element of convergence and cross-talk between distinct signaling pathways, rather than as a target of one single pathway. Studies on $\mathrm{Ca}^{2+}$ signal transduction in PC12 cells and hippocampal neurons have proposed that $\mathrm{CaM}$ kinases may be the $\mathrm{Ca}^{2+}$-activated enzymes that phosphorylate CREB on membrane depolarization (Sheng et al., 1991; Deisseroth et al., 1996). Our results in OP cells indicate that CaM kinases are involved in the transduction of $\mathrm{Ca}^{2+}$ signals to the nucleus to a lesser extent than the MAPK pathway (Fig. 7). Such differential contribution of the $\mathrm{Ca}^{2+}$ signaling pathways to $\mathrm{CREB}$ phosphorylation may be attributable to the different neural cell types analyzed in these studies. On the other hand, it should also be noted that in the cellular systems considered previously, voltage-dependent $\mathrm{Ca}^{2+}$ channels (Sheng et al., 1991) and NMDA receptors (Deisseroth et al., 1996) were the major source of $\mathrm{Ca}^{2+}$ entry, whereas in OP cells stimulated with kainate and carbachol, $\mathrm{Ca}^{2+}$ flows into the cells through different channels, i.e., mainly non-NMDA receptors and store-operated channels. It is therefore possible that the route of $\mathrm{Ca}^{2+}$ entry affects which pathways propagate $\mathrm{Ca}^{2+}$ signals to the nucleus.

CREB phosphorylation at Ser-133 is usually followed by transcriptional activation of CRE-dependent genes (Gonzalez and Montminy, 1989; Sheng et al., 1991; Ginty et al., 1994; Xing et al., 1996). The mechanism underlying this process involves the binding of P-Ser-133 CREB to a CREB binding protein (CBP) (Chrivia et al., 1993), followed by interaction of this complex with the basal transcriptional machinery; however, the transactivation potential of CREB may be controlled by some additional events (Sun et al., 1994; Nakajima et al., 1996). The complexity of CREB regulation has been emphasized recently by two separate studies, which are particularly relevant for our analysis. Xing et al. (1996) reported that RSK2, a member of the RSK family of protein kinases, promoted CREB activation by phosphorylating the Ser133 residue. On the other hand, Nakajima et al. (1996) proposed that RSK might interfere negatively with the CREB-mediated transactivation by inhibiting CBP function. Clearly, additional studies are needed to clarify the physiological role of the MAPK/ RSK pathway on the regulation of CRE-dependent transcription on growth factor stimulation as well as $\mathrm{Ca}^{2+}$ influx.

Oligodendrocyte development is tightly regulated by cAMP levels (McMorris et al., 1990), growth factors (Barres and Raff, 1994), and ion fluxes (Gallo et al., 1996). Our results identify molecular mechanisms that in OP cells can convey the information of these distinct signals to nuclear factors. These studies therefore may provide the basis for understanding how different environmental signals influence developmental progression of oligodendroglial cells.

\section{REFERENCES}

Aderem A (1992) The MARCKS brothers: a family of protein kinase C substrates. Cell 71:713-716.

Alessi DR, Cuenda A, Cohen P, Dudley DT, Saltiel A (1995) PD 098059 is a specific inhibitor of the activation of mitogen-activated protein kinase kinase in vitro and in vivo. J Biol Chem 270:27489-27494.

Bading H, Ginty DD, Greenberg ME (1993) Regulation of gene expression in hippocampal neurons by distinct calcium signaling pathways. Science 260:181-186.

Barres BA, Raff MC (1994) Control of oligodendrocyte number in the developing rat optic nerve. Neuron 12:935-942.

Berridge MJ, Irvine RF (1989) Inositol phosphate and cell signaling. Nature 341:197-205.

Blenis J (1993) Signal transduction via the MAP kinases: proceed at your own RSK. Proc Natl Acad Sci USA 90:5889-5892.

Böhm M, Moellmann G, Cheng E, Alvarez-Franco M, Wagner S, SassoneCorsi P, Halaban R (1995) Identification of $\mathrm{p} 90^{\mathrm{RSK}}$ as the probable CREB-Ser ${ }^{133}$ kinase in human melanocytes. Cell Growth Differ 6:291-302.

Bourtchuladze R, Frenguelli B, Blendy J, Cioffi D, Schütz G, Silva AJ (1994) Deficient long-term memory in mice with a targeted mutation of the cAMP-responsive element-binding protein. Cell 79:59-68.

Burgering BMT, de Vries-Smits AMM, Medema RH, van Weeren PC, Tertoolen LGJ, Bos JL (1993) Epidermal growth factor induces phosphorylation of extracellular signal-regulated kinase 2 via multiple pathways. Mol Cell Biol 13:7248-7256.

Clapham DE (1995) Calcium signaling. Cell 80:259-268.

Clapham DE (1996) TRP is cracked but is CRAC TRP? Neuron 16:1069-1072.

Chen R-H, Blenis J (1990) Identification of Xenopus S6 protein kinase homologs $\left(\mathrm{pp} 90^{\mathrm{rsk}}\right)$ in somatic cells: phosphorylation and activation during initiation of cell proliferation. Mol Cell Biol 10:3204-3215.

Chrivia JC, Kwok RPS, Lamb N, Hagiwara M, Montminy MR, Goodman RH (1993) Phosphorylated CREB binds specifically to the nuclear protein CBP. Nature 365:855-859.

Chung J, Kuo CJ, Crabtree GR, Blenis J (1992) Rapamycin-FKBP specifically blocks growth-dependent activation of and signaling by the 70 kd S6 protein kinases. Cell 69:1227-1236.

Cohen RI, Almazan G (1994) Rat oligodendrocytes express muscarinic receptors coupled to phosphoinositide hydrolysis and adenylyl cyclase. Eur J Neurosci 6:1213-1224.

de Groot RP, den Hertog J, Vandenheede JR, Goris J, Sassone-Corsi P (1993) Multiple and cooperative phosphorylation events regulate the CREM activator function. EMBO J 12:3903-3911.

de Groot RP, Ballou LM, Sassone-Corsi P (1994) Positive regulation of the cAMP-responsive activator CREM by the p70 S6 kinase: an alternative route to mitogen-induced gene expression. Cell 79:81-91.

Deisseroth K, Bito H, Tsien R (1996) Signaling from synapse to nucleus: postsynaptic CREB phosphorylation during multiple forms of hippocampal synaptic plasticity. Neuron 16:89-101.

Downward J (1995) KSR: a novel player in the RAS pathway. Cell 83:831-834.

Dubois-Dalcq M, Armstrong RC (1992) The oligodendrocyte lineage during myelination and remyelination. In: Myelin: biology and chemistry (Martenson RE, ed), pp 81-122. Boca Raton, FL: CRC Press.

Dudley DT, Pang L, Decker SJ, Bridges AJ, Saltiel AR (1995) A synthetic inhibitor of the mitogen-activated protein kinase cascade. Proc Natl Acad Sci USA 92:7686-7689.

Enslen H, Soderling TR (1994) Roles of calmodulin-dependent protein kinases and phosphatases in calcium-dependent transcription of immediate early genes. J Biol Chem 269:20872-20877.

Farnsworth CL, Freshney NW, Rosen LB, Ghosh A, Greenberg ME, Feig LA (1995) Calcium activation of Ras mediated by neuronal exchange factor Ras-GRF. Nature 376:524-527.

Fatatis A, Russell J (1992) Spontaneous changes in intracellular calcium 
concentration in type 1 astrocytes from rat cerebral cortex in primary culture. Glia 5:95-104.

Finkbeiner SM (1993) Glial calcium. Glia 9:83-104.

Finkbeiner S, Greenberg ME (1996) $\mathrm{Ca}^{2+}$-dependent routes to Ras: mechanisms for neuronal survival, differentiation, and plasticity? Neuron 16:233-236.

Fisher TL, Blenis J (1996) Evidence for two catalytically active kinase domains in pp90 ${ }^{\text {rsk }}$. Mol Cell Biol 16:1212-1219.

Fulton BP, Burne JF, Raff MC (1992) Visualization of O-2A progenitor cells in developing and adult rat optic nerve by quisqualate-stimulated cobalt uptake. J Neurosci 12:4816-4833.

Gallo V, Armstrong RC (1995) Developmental and growth factorinduced regulation of nestin in oligodendrocyte lineage cells. J Neurosci 15:394-406.

Gallo V, Zhou JM, McBain CJ, Wright P, Knutson PL, Armstrong RC (1996) Oligodendrocyte progenitor cell proliferation and lineage progression are regulated by glutamate receptor-mediated $\mathrm{K}^{+}$channel block. J Neurosci 16:2659-2670.

Ghosh A, Greenberg ME (1995) Calcium signaling in neurons: molecular mechanisms and cellular consequences. Science 268:239-247.

Ginty DD, Kornhauser JM, Thompson MA, Bading H, Mayo KE, Takahashi JS, Greenberg ME (1993) Regulation of CREB phosphorylation in the suprachiasmatic nucleus by light and a circadian clock. Science 260:238-241.

Ginty DD, Bonni A, Greenberg ME (1994) Nerve growth factor activates a Ras-dependent protein kinase that stimulates $c$-fos transcription via phosphorylation of CREB. Cell 77:713-725.

Gonzalez GA, Montminy MR (1989) Cyclic AMP stimulates somatostatin gene transcription by phosphorylation of CREB at Serine 133. Cell 59:675-680.

Hart IK, Richardson WD, Bolsover SR, Raff MC (1989) PDGF and intracellular signaling in the timing of oligodendrocyte differentiation. J Cell Biol 109:3411-3417.

Holtzclaw L, Gallo V, Russell JT (1995) AMPA receptors shape $\mathrm{Ca}^{2+}$ responses in cortical oligodendrocyte progenitors and CG-4 cells. J Neurosci Res 42:124-130.

Kolch W, Heidecker G, Kochs G, Hummel R, Vahidi H, Mischak H, Finkenzeller G, Marmé D, Rapp UR (1993) Protein kinase C $\alpha$ activates RAF-1 by direct phosphorylation. Nature 364:249-252.

Lev S, Moreno H, Martinez R, Canoll P, Peles E, Musacchio JM, Plowman GD, Rudy B, Schlessinger J (1995) Protein tyrosine kinase PYK2 involved in $\mathrm{Ca}^{2+}$-induced regulation of ion channel and MAP kinase function. Nature 376:737-745.

Louis J-C, Magal E, Muir D, Manthorpe M, Varon S (1992) CG-4, a new bipotential cell line from rat brain, is capable of differentiating in vitro into either mature oligodendrocytes or type-2 astrocytes. J Neurosci Res 31:193-204.

Maldonado R, Blendy JA, Tzavara E, Gass P, Roques BP, Hanoune J, Schütz G (1996) Reduction of morphine abstinence in mice with a mutation in the gene encoding CREB. Science 273:657-659.

Marais R, Light Y, Paterson HF, Marshall CJ (1995) Ras recruit Raf-1 to plasma membrane for activation by tyrosine phosphorylation. EMBO J $14: 3136-3145$.

Marshall CJ (1995) Specificity of receptor tyrosine kinase signaling: transient versus sustained extracellular signal-regulated kinase activation. Cell 80:179-185.

Mayer ML, Miller RJ (1990) Excitatory amino acid receptors, second messengers and regulation of intracellular $\mathrm{Ca}^{2+}$ in mammalian neurons. Trends Pharmacol Sci 11:36-42.

McMorris FA, Furlanetto RW, Mozell RL, Carson MJ, Raible DW (1990) Regulation of oligodendrocyte development by insulin-like growth factors and cyclic nucleotides. Ann NY Acad Sci 605:101-109.

McNicol M, Bennett Jefferson A, Schulman H (1990) $\mathrm{Ca}^{2+} /$ calmodulin is activated by the phosphatidylinositol signaling pathway and becomes $\mathrm{Ca}^{2+}$-independent in PC12 cells. J Biol Chem 265:18055-18058.

Meucci O, Fatatis A, Holzwarth JA, Miller R (1996) Developmental regulation of the toxin sensitivity of $\mathrm{Ca}^{2+}$-permeable AMPA receptors in cortical glia. J Neurosci 16:519-530.
Nakajima T, Fukamizu A, Takahashi J, Gage FH, Fisher T, Blenis J, Montminy M (1996) The signal-dependent coactivator CBP is a nuclear target for pp 90 ${ }_{\mathrm{RSK}}$. Cell 86:465-474.

Patneau DK, Wright PW, Winters CA, Mayer ML, Gallo V (1994) Glial cells of the oligodendrocyte lineage express both kainate- and AMPApreferring subtypes of glutamate receptors. Neuron 12:357-371.

Pende M, Holtzclaw LA, Curtis JL, Russell JT, Gallo V (1994) Glutamate regulates intracellular calcium and gene expression in oligodendrocyte progenitors through the activation of DL- $\alpha$-amino-3-hydroxy-5methyl-4-isoxazolepropionic acid receptors. Proc Natl Acad Sci USA 91:3215-3219.

Puchalski RB, Louis J-C, Brose N, Traynelis SF, Egebjerg J, Kukekov V, Wenthold RJ, Rogers SW, Lin F, Moran T, Morrison JH, Heinemann SF (1994) Selective RNA editing and subunit assembly of native glutamate receptors. Neuron 13:131-147.

Rosen LB, Greenberg ME (1996) Stimulation of growth factor receptor signal transduction by activation of voltage-sensitive calcium channels. Proc Natl Acad Sci USA 93:1113-1118.

Rosen LB, Ginty DD, Weber MJ, Greenberg ME (1994) Membrane depolarization and calcium influx stimulate MEK and MAP kinase via activation of Ras. Neuron 12:1207-1221.

Rusanescu G, Qi H, Thomas S, Brugge JS, Halegoua S (1995) Calcium influx induces neurite growth through a Src-Ras signaling cassette. Neuron 15:1415-1425.

Sato-Bigbee C, Yu RK (1993) Presence of cAMP response elementbinding protein in rat oligodendrocytes. J Neurochem 60:2106-2110.

Sheng M, McFadden G, Greenberg ME (1990) Membrane depolarization and calcium induce $c$-fos transcription via phosphorylation of transcription factor CREB. Neuron 4:571-582.

Sheng M, Thompson M, Greenberg ME (1991) CREB: a $\mathrm{Ca}^{2+}$-regulated transcription factor phosphorylated by $\mathrm{CaM}$ kinases. Science 252:1427-1430

Simpson PB, Challiss RAJ, Nahorski SR (1995) Neuronal $\mathrm{Ca}^{2+}$ storesactivation and function. Trends Neurosci 18:299-306.

Skene JHP (1989) Axonal growth-associated proteins. Annu Rev Neurosci 12:127-156.

Steinhauser C, Gallo V (1996) News on glutamate receptors in glial cells. Trends Neurosci 19:339-345.

Sumi M, Kikuchi K, Ishikawa T, Ishii A, Hagiwara M, Nagatsu T, Hidaka $\mathrm{H}$ (1991) The newly synthesized selective $\mathrm{Ca}^{2+} /$ calmodulin dependent protein kinase II inhibitor KN-93 reduces dopamine contents in PC12 cells. Biochem Biophys Res Commun 181:968-975.

Sun P, Enslen H, Myung PS, Maurer RA (1994) Differential activation of CREB by $\mathrm{Ca}^{2+} /$ calmodulin-dependent protein kinases type II and type IV involves phosphorylation of a site that negatively regulates activity. Genes Dev 8:2527-2539.

Treisman R (1996) Regulation of transcription by MAP kinase cascade. Curr Opin Cell Biol 8:205-215.

Tsien RY (1980) New calcium indicators and buffers with high selectivity against magnesium and protons: design, synthesis and properties of the prototype structures. Biochemistry 19:2396-2404.

Vaccarino FM, Liljequist S, Tallman JF (1991) Modulation of protein kinase $\mathrm{C}$ translocation by excitatory and inhibitory amino acids in primary cultures of neurons. J Neurochem 57:391-396.

Vik TA, Sweet LJ, Erikson RL (1990) Coinfection of insect cells with recombinant baculovirus expressing pp60v-src results in the activation of a serine-specific protein kinase pp90rsk. Proc Natl Acad Sci USA $87: 2685-2689$

Yagodin SV, Holtzclaw L, Sheppard CA, Russell JT (1994) Non-linear propagation of agonist-induced cytoplasmic calcium waves in single astrocytes. J Neurobiol 25:265-280.

Yamamoto KK, Gonzalez GA, Biggs III WH, Montminy MR (1988) Phosphorylation-induced binding and transcriptional efficacy of nuclear factor CREB. Nature 334:494-498.

Xing J, Ginty DD, Greenberg ME (1996) Coupling of the RAS-MAPK pathway to gene activation by RSK2, a growth factor-regulated CREB kinase. Science 273:959-963. 